\title{
Sweet Potato Production for Poverty Alleviation in Nasarawa State, Nigeria
}

\author{
Aboajah F.N. ${ }^{1 *}$, Ejechi M.E ${ }^{2}$, Viashima, S.S ${ }^{1}$, Adeyongu, S.K. ${ }^{1}$, Muogbo P.C. ${ }^{3}$ \\ ${ }^{1}$ National Root Crops Research Institute, Umudike, Otobi Sub-Station, Otobi, Otukpo LGA., Benue State \\ ${ }^{2}$ National Root Crops Research Institute, Umudike, Abia State \\ ${ }^{3}$ National Root Crops Research Institute, Umudike, Nyanya Sub-Station, Abuja
}

\begin{abstract}
The study investigated sweet potato production for poverty alleviation in Nasarawa State of Nigeria. Data were collected from 180 sweet potato farmers randomly selected from Keffi, Kokona and Karu Local Government Areas and interviewed using structured interview schedule. Results of the study show that adult males played a dominant role in sweet potato production especially in land preparation $79 \%$ and ridging $81 \%$ respectively, while women and children played major role in planting 97\%, weeding $94 \%$ and harvesting $93 \%$ in the area. The study further reveals that if sweet potato is well managed, it has the potential for food security and alleviating farmers from their poverty. This suggests that sweet potato should be given adequate attention in terms of production, value addition and marketability.
\end{abstract}

Keywords - Sweet potato, production, poverty alleviation, value addition, gender.

\section{INTRODUCTION}

Sweet potato (Ipomoea batatas) is a creeper of the Convolvulaceae family. It originated from Central America and is widely grown as important staple food in most parts of the world. Presently, Nigeria is number one producer of sweet potato in Africa with annual output of 3.46million metric tons (FAO, 2006) and globally the second largest producer after China. The crop is grown for both human and animal consumption. Sweet potato is the only crop among the root and tuber crops that has a positive per capita annual rate of increase in production in Sub-Saharan Africa (Tewe et al, 2003). It is the only member of the genus ipomoea whose roots are edible and is one of the world's most important foods crops due to its high yield and nutritive value (Data and Eronico, 1987). According to Chukwu (2001), within the root crop belt of Nigeria, especially the South-East agro-ecological zone, sweet potato has joined the league of life saving-crops as cassava. It blends well with rice, cowpea and plantain in most diets (Ejechi et al., 2009). Fawole (2007) reported that sweet potato remains one of the three most important root crops in the world. In spite of these important aspects, less research has been done on sweet potato than on the other roots crops. The other major root crops, for instance, have had ongoing systemic studies for decades. Therefore, there is a dearth of information on the economics of sweet potato production in Nigeria.

The high agronomic potentials of sweet potato has been established at the International Institute of Tropical Agriculture (IITA) and the National Root Crops Research Institute (NRCRI), which are both located in the humid zone of Nigeria (Tewe et al, 2003). Its production provides job opportunity for the farmers, thus raising their income. Sweet potato is consumed without much processing in most parts of the Tropics. It is either eaten boiled, roasted or fried. Although sweet potato is a crop that is consumed in all parts of the country, its level of production still remains low. The crop ranks among the five most important food crops in over 50 developing countries (All about sweet potato, 2008).The roots can also be slightly fermented in water for 2-3 days to reduce the sweetness, then sun dried and milled, mixed with either yam or cassava flour for eating. The leaves and tender shoots of sweet potato are used as vegetable food. The leaves contain, on dry matter basis about $8 \%$ starch $4 \%$ sugar $27 \%$ protein and vitamins therefore are very nutritious. It also contains about $56 \mathrm{mg}$ carotene per $100 \mathrm{~kg}$ dry matter. The leaves are usually eaten boiled or incorporated into soup and stews (Matthew et al, 2008).

Industrially, sweet potato flour can be used to substitute wheat bread making or maize flour in balanced feeds. Baby foods have been formulated using sweet potato while some bakeries blend $15-30 \%$ of sweet potato flour for making bread and 20-30\% for pastries. It is also used in the brewing of alcoholic drinks and as sweeteners in non-alcoholics drinks. (Agbo and Ene,1992). Sweet potato starch can also have medicinal value. According to Hartwell (1971), the leafs decoction is used in folk remedies for tumor of the mouth and throat. Reported to be alternative, aphrodisiac, astringent, bactericide, demulcent, fungicide, laxative and

Page | $\mathbf{3 8 0}$ 
tonic, industrial potentials of sweet potato have not been fully exploited due mainly to a chronic lack, of awareness of the commercial benefits derivable from sweet potato (Azgogu and Olomo, 2002). Little research is known to have been undertaken on the economics of sweet potato production compared to other roots and tubers like cassava and yam (Azogu and Olomo). Cultivation of root and tuber crops in Nigeria as in most Africa countries is threatened by the low prices of the crops and their products.

With the rising cost of labour and transportation, rural farmers can hardly sustain their farming systems considering the meager returns from their harvest. It is therefore advantageous to diversify the use of crop roots beyond those of the traditional food industry in Africa countries. Because sweet potato surpasses other root crops in terms of agronomic potentials, diversification into other food, feed and industrial uses will increase demand, ensure attractive prices and consequently encouraged farmers, to sustain and expand their root crop farming units.

In order to solve the problem of hunger in the society, there is need to increase production of crops with minimum effort, find market for the produce and improves its quality for acceptability by the public. Sweet potato is one of such crops. It requires minimum management practices such as weeding and fertilizer application. Hence the objectives of this study were: (i) to describe the socio-economic characteristics of the respondents (ii) determine the gender roles of families in the production of sweet potato (iii) to access the consumption rate of sweet potato (iv) to access marketability of sweet potato

\section{METHODOLOGY}

The survey was conducted in Karu, Kokona and Keffi of Nasarawa State, in 2016 to examine sweet potato production for poverty alleviation in Nasarawa State of Nigeria. The three agricultural zones in the area study were purposively selected based on strategic importance of sweet potato in the farming system of the sampled zones in the area. In each zone one Local Government Area was selected by simple random sampling technique from the list of all Local Government Areas in the State. Then in each Local Government Area, 6 communities were similarly selected by random sampling technique, and in each community, 10 sweet potato farmers were equally selected through the same sampling technique. 60 Respondents were obtained from each agricultural zone making up a sample size of 180 respondents for the entire study area, using structured questionnaires, relevant data on house hold sweet potato production were collected from the respondents. Data were analyzed with descriptive statistics.

\section{RESULTS AND DISCUSSION} Socio-economic Characteristics of Respondents Sex

Result from Table 1 showed that majority of the respondents were male farmers $(62.2 \%)$

for Nasarawa State, while the female farmers accounted for (37.8).

Age

Result from Table 1 also showed that majority of the farmers age bracket 21-30 accounted for 0\% in Nasarawa State. Age bracket 31-40 accounted for 5.0\% 41-50 accounted for $21.1 \%, 51-60$ accounted for $37.2 \%$, greater than 60 years accounted for $36.7 \%$. From the above, it can be seen that they have able people for farming activities. This means, if the advantage of these able men are taken, production will increase, poverty and unemployment will be reduced.

\section{Marital Status}

With reference to table $1,90.0 \%$ of the respondents are in Nasarawa State are married, $6.7 \%$ and $3.3 \%$ are single and widowed in Nasarawa State, respectively. The marital status of the farmers account for marital stability, which accounted for higher productivity.

\section{Level of Education}

Majority of the respondent's table1 had formal Education; Tertiary education accounted for $7.2 \%$ in Nasarawa State, Secondary education constituted $15.6 \%$ for Nasarawa State, Primary education accounted for $32.8 \%$ for Nasarawa State. While Those farmers who had no education accounted for $44.4 \%$ for Nasarawa State. The state has fairly educated farmers, which could make adequate use of agricultural information for optimal production.

\section{Household Size}

With reference to Table 1 the average household size of 1-5 accounted for $5.0 \%$ for Nasarawa State, 6-10 constituted $35.6 \%, 11-15$ accounted for $21.7 \%$ while $16-20$ accounted for $24.4 \%$ and above 20 accounted $13.3 \%$, respectively. In the absence of adult males, underage males were in some places designated household heads. In all, $88 \%$ of the households were male headed and $12 \%$ female headed.

\section{Major Occupation}

The result from table 1, showed that occupation of majority of the farmers in Nasarawa State is 100\%

\section{Farm experience in Farming of Sweet potato}

The result from table 1 showed that $14.9 \%$ of the respondents in Nasarawa State had between 1-5 years experience in sweet potato farming. 6-10 had 25.6\%, 11-15 had $22.8 \%, 16-20$ had $15 \%$ and above 20 had $21.7 \%$, respectively. 
Farm Size

Majority of the respondents table1 Nasarawa State accounted for $35 \%$ between $1-2$ ha, $35 \%$ between $3-4$ ha, $15 \%$ between 5-6ha, while above 6ha accounted for $14.9 \%$, respectively. Their hectarage is quite small because more than $62 \%$ in Nasarawa State fall within 1-2ha. Which implies that their production output is still very low, which has contributed to their poverty and unemployment.

\section{Association Membership}

The results showed that $98.9 \%$ of the farmers belong to sweet potato grower association of Nigeria (POGMAN) while $1.1 \%$ does not belong to any group in Nasarawa State while in FCT State (POGMAN) accounted for $80 \%$ membership, (ECOMC) accounted for $3.3 \%$ while (CBNCO) accounted for $0.6 \%$ and no response accounted for $6.1 \%$ Table 1

\section{Estimated Annual On-Farm Income}

The distribution of respondents according to their income revealed that about $68.5 \%$ of the respondents had annual income of between N20,000 - N100,000, while $25.0 \%$ had $\mathrm{N} 101,000-\mathrm{N} 500,000$ and $6.1 \%$ had N501,000 $\mathrm{N} 1,000.000$. The mean annual income was (N196, 226.50).Farmers with low income will not be able to purchase subsidized farm inputs provided by the government. This implies that respondents with high farm income are most likely to purchase government inputs.

\section{Membership of Organizations}

Distribution of the respondents according to their membership of organization revealed that $96.2 \%$ belonged to organizations and the remaining $3.8 \%$ did not belong to any. Being a member of any organization could be an avenue for accessing information on increased productivity. Fertilizer use

The fertilizer used was procured from Federal and State government fertilizer programme. Because of the delay of the fertilizer getting to the farmers, the percentage usage by farmers was quite encouraging.

\section{Estimated Annual Off-Farm Income}

Distribution of respondents according to their annual offfarm income revealed that $53.9 \%$ had annual off-farm income of between $\mathrm{N} 20,000-\mathrm{N} 50,000$, followed byN51,000 N100,000 (24.4\%), N101,000 - N150,000 (6.7\%), N151,000 - N200,000 (10.6\%) and N201,000 $\mathrm{N} 250,000$ (4.4\%), respectively. The mean off-farm income was N38, 127.50. This is in addition to the annual on-farm income which could assist the farmer in purchasing more subsidized inputs to increase production.

\section{Planting Materials}

Distribution of respondents according to the plant materials grown by farmers' revealed that $87.2 \%$ of the respondents got their materials from International Institute for Tropical Agriculture, Ibadan and National Roots Crops Research Institute Umudike, Abia State, Nigeria. While the remaining $12.8 \%$ got their planting materials from local vendors.

\section{Labour Use}

Majority $83.3 \%$ of the respondents use family labour while the remaining $16.7 \%$ used hired labour.

Table.1: Distribution of Socio-economic Characteristics of the Respondents

\begin{tabular}{|c|c|c|c|}
\hline \multirow{2}{*}{$\begin{array}{l}\text { Socio-economic } \\
\text { Characteristics }\end{array}$} & \multicolumn{3}{|c|}{ Nasarawa $(n=180)$} \\
\hline & Freq & $\%$ & Mean \\
\hline \multicolumn{4}{|l|}{ Sex: } \\
\hline Male & 112 & 62.2 & \\
\hline Female & 68 & 37.8 & \\
\hline \multicolumn{4}{|l|}{ Age(years) } \\
\hline $21-30$ & - & 0 & \\
\hline $31-40$ & 9 & 5.0 & \\
\hline $41-50$ & 38 & 21.1 & \\
\hline $51-60$ & 67 & 37.2 & \\
\hline$>60$ & 66 & 36.7 & 53.1 \\
\hline \multicolumn{4}{|l|}{ Marital Status } \\
\hline Single & 12 & 6.7 & \\
\hline Married & 162 & 90.0 & \\
\hline Widowed & 6 & 3.3 & \\
\hline Divorced & - & - & \\
\hline
\end{tabular}


Level of Education

No formal education

80

Primary education

Secondary education

Tertiary education

Mean of years spent in

Acquiring formal education

\section{Household size}

(number)

$1-5$

$6-10$

$11-15$

$16-20$

$>20$

Major occupation

Farming

Fishing

Farming/Trading

Hunting

Farming experience(years)

$1-5$

$6-10$

$11-15$

$16-20$

$>20$

Farm size (hectares)

$1-2$

$3-4$

$5-6$

$>6$

Estimated Annual Onfarm Income (Naira)

$20,000-100,000$

$101,000-500,000$

$501,000-1,000,000$

Fertilizer use

Fertilizer purchase from

Government

Not purchase from

Government

Membership of

Organizations

Yes
44.4

32.8

15.6

7.2

8.4
$9 \quad 5.0$

$64 \quad 35.6$

$39 \quad 21.7$

$44 \quad 24.4$

$24 \quad 13.3$

13

$180 \quad 100$

- $\quad-$

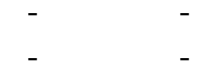

$27 \quad 14.9$

$46 \quad 25.6$

$41 \quad 22.8$

$27 \quad 15.0$

$39 \quad 21.7$

13.3

$63 \quad 35.0$

$63 \quad 35.0$

$27 \quad 15.0$

$\begin{array}{lll}27 & 14.9 & 3.3\end{array}$

$124 \quad 68.5$

$45 \quad 25.0$

$11 \quad 6.1$

$196,226.5$

$171 \quad 95$

95 
No

Planting materials

IITA/NRCRI

Other vendors
$157 \quad 87.2$

$23 \quad 12.8$

Family labour

Hired Labour
$173 \quad 96.2$

$7 \quad 3.8$

Estimated Annual Off-
farm Income (Naira)

$150 \quad 83.3$

$30 \quad 16.7$

$20,000-50,000$

$51,000-100,000$

$101,000-150,000 \quad 97 \quad 53.9$

$151,000-200,000 \quad 44 \quad 24.4$

$\begin{array}{lll}201,000-250,000 & 12 & 6.7\end{array}$

$19 \quad 10.6$

$8 \quad 4.438,958$

Total

$180 \quad 100$

Source: Field Survey, 2009

Importance of sweet potato as a food security and cash crop.

Overall, sweet potato's most important role in Nigeria was as a supplementary food security crop, (Table 3 ), showed that Nasarawa State, still ranked $3^{\text {rd }}$ in food importance and share $1^{\text {st }}$ in cash with groundnut $35 \%$ each. Sorghum was the most important food security crop in Nasarawa State.
The survey reported that a woman in the household was engaged in sweet potato selling and most of the women ranked sweet potato as their most important cash crop. Sweet potato's importance as the principal cash crop varied considerably by area, with it being an extremely important source of cash for women in Nasarawa State.

Table.2: Ranking of importance of sweet potato as a food security and as a source of cash

\begin{tabular}{lllll}
\hline Ranking Nasarawa State & & & \\
& $\mathrm{Mz}$ & $\mathrm{Sg}$ & $\mathrm{Sp}$ & $\mathrm{Gn}$ \\
\hline & & & & \\
Food security & 26 & 39 & 25 & 10 \\
Cash crop: & 18 & 12 & 35 & 35
\end{tabular}

Source: Aboajah 2009 survey. Mz - maize, Sg- sorghum, Sp- sweet potato, Gn- groundnut

Sweet potato (Ipomoea batatas) is an important subsistence food security crop grown on a small-scale in the densely populated, mid- elevation areas $(1,200-2,000 \mathrm{~m})$ of North Central Nigeria. It is a major staple food in North Central Nigeria by extension in Nigeria and a secondary food crop in the grain- based food systems of North Central Nigeria. The crop is vegetatively propagated, requires low inputs for cultivation and produces modest yields of storage roots (Ewell 1993). The storage roots have a low dry matter content (30\% of the roots), with starch being the major component (Hagenimana1994). Like other root and tuber crops, fresh sweet potato does not store well because of its high moisture content. The high moisture content also make it's the crop bulky and therefore costly to transport over long distances. These attributes have made sweet potato and other root and tuber crops essentially crops for rural consumption, in setting where the chain from the producer to consumer is short. The sweet potato storage roots are usually harvested a little at a time as needed over an extended period. Harvesting this way provides a flexible source of food for households (Smit and Ocitti p' Obwoya 1994). 
Sweet Potato production, consumption and food security

Sweet Potato is the fourth most important food crop in the world (IITA, 2002). The World's annual output is greater than annual output of all other roots and tuber crops (FAOSTAT, 2008). Sweet potato is cultivated in 140 countries and more than 100 of which are located in the tropical and sub-tropical zones (Beukema et al. 1990). Annual world production currently totals 314.37 million tones and covers 19.55 million hectares (FAOSTAT, 2008). More than a million people worldwide eat sweet potato and the crop forms an important part of the diet of more than half a billion consumers in developing countries (FAOSTAT, 2008). In Africa, Nigeria occupies the seventh position in terms of total sweet potato production, 840,000 tonnes in 2007. This implies that with the average market price of $\$ 70$, 000/tones in 2007 over $\$ 5$ billion circulated in the Nigerian economy through sweet potato production. Aboajah (2009) revealed in a study on sweet potato consumption pattern of households, that households in North Central Nigeria spend only $10 \%$ of their food budget on sweet potato. Similarly, FAOSTAT (2008) reported that Nigeria has the lowest per capital sweet potato consumption of $3.27 \mathrm{~kg}$ in Africa. The households in Nasarawa State of North Central Nigeria also identified sweet potato being a staple food crop, nutritional content convenient fast food, easy to cook compared with other food crops as most important factors influencing sweet potato consumption. These cardinal issues are paramount in solving food security problems. Nigerian's estimated cultivated area under sweet potato in 2007 is 266,000 hectares with an average yield of 3.27 tonnes/ha (FAOSTAT, 2008).

\section{Labour Contribution by Gender to Farm Activities} (Sweet potato) Nasarawa State

The contribution of labour by gender in farmers of activities showed that in land preparation in Nasarawa State Adult male account for $(79 \%)$ adult female $(3 \%)$, male children (16\%) and female children $2 \%$. Ridging, in Nasarawa State Adult male accounted for $(81 \%)$, Adult female (2\%), male children (16\%) and female children (17\%).planting activities in Nasarawa State adult male accounted for $(3 \%)$ in weeding, adult female accounted for (53\%), male children accounted for $(8 \%)$ in harvesting adult female accounted for $21 \%$, children male and female accounted for $72 \%$, respectively. From the table above, showed clearly that adult male and male children are more involved in land preparation and ridging while their counterpart are pruned more in planting, weeding and harvesting. Table 3
Table.3: Contribution by Gender to Farm Activities

\begin{tabular}{|l|l|l|l|l|}
\hline \multicolumn{5}{|c|}{ NASARAWA } \\
\hline Activities & Adult M & Adult F & MC & FC \\
\hline $\begin{array}{l}\text { Land } \\
\text { Preparation }\end{array}$ & 79 & 3 & 16 & 2 \\
\hline Ridging & 81 & 2 & 16 & 1 \\
\hline Planting & 3 & 74 & 10 & 13 \\
\hline Weeding & 8 & 53 & 21 & 18 \\
\hline Harvesting & 7 & 21 & 38 & 34 \\
\hline
\end{tabular}

Adult $\mathrm{M}=$ Adult male, Adult $\mathrm{F}=$ Adult female, $\mathrm{MC}=$ Male child and $\mathrm{FC}=$ female child

\section{Income from Sales of Sweet potato}

Total amount for sweet potato sales in Nasarawa State, there was a total of $\$ 286,300$ of which Keffi accounted for $32.4 \%$, Karu $34.7 \%$ and Kokona $32.0 \%$ with the average

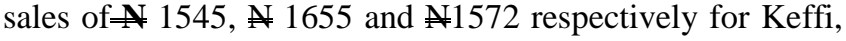
Karu and Kokona.

From the above, the survey show that while Keffi in Nasarawa has the least with $\cong 1545$. Table4.

Table.4: Income from Sweet Potato Sales

\begin{tabular}{|l|l|l|l|}
\hline \multicolumn{4}{|c|}{ NASARAWA } \\
\hline \multicolumn{2}{|c|}{$\begin{array}{l}\text { Amount ( } \\
\text { SWET POTATO SALES }\end{array}$} & $\begin{array}{l}\text { Total } \\
\text { Sales }\end{array}$ & Average \\
\hline Keffi & 99,200 & 32.4 & 1545 \\
\hline Karu & 99,300 & 34.7 & 1655 \\
\hline Kokona & 94,300 & 32.9 & 1572 \\
\hline Total & 286,300 & 100 & 4772 \\
\hline
\end{tabular}

\section{CONCLUSION}

The consumption patterns of sweet potato in the surveyed areas indicates that the crop is a major staple food in the diet of Nasarawa State by extension Nigeria. However, the utilization base of sweet potato is mainly limited to boiled or steamed roots for food and minimal feeding of vines and peelings to livestock. There is virtually no storage of mature fresh roots except in-ground as a crop and there is very little processing. The most important role of sweet potato is that it is a food security crop. Developing early maturity and drought tolerant varieties that are resistant/ tolerant to major pests and diseases would help fill the gap during sweet potato scarcity when demand is high. Demand of sweet potato is high immediately after drought period. There is need for research into the utilization of vines for food, feed, identifying varieties with good drying and processing properties, developing low-cost post harvesting storage technologies and processing sweet potato into food, animal feed and other products to stimulate production and increase income generation among farmers. The war against food security, which is expressed as inadequate food supply, 
instability in its availability and un-affordability by consumers, could be fought by effective use and production of sweet potato. The conductive climate in Nasarawa State which allows for three cycles of sweet potato production in a year makes sweet potato highest yielding tuber crop if adequate attention is focused on research. The high nutrients content of sweet potato is an added advantage in food security. The Sweet Potato Research Programme has been playing the leading role in sweet potato research and in expanding sweet potato production to new frontiers. Sweet potato from the last decade experienced a remarkable increase because of its activities as food security crop.

For sweet potato crop to play more roles in food security and poverty alleviation in Nigeria,if well manage could boost the nation economic and reduce poverty. Sweet potato production, processing and marketing are still at subsistence level.

\section{RECOMMENDATIONS}

Varieties with good processing qualities should be scaled up through research

a. Proper funding and provision of infrastructure and other equipments necessary in research activities

b. Promotion of efforts to seek non-traditional funding for research and development of R\&T.

c. Policy makers also need to be sensitive to the allocation of resources within national $\mathrm{R} \& \mathrm{~T}$ programme in order to ensure that post-production activities is not underfunded in relation to production research

d. The problem of food insecurity in the study area can be reduced if sweet potato consumption and processing techniques are encouraged.

e. The study area need to reduce ignorance about food forms, correct faulty food habits to improve on the supply of food available.

f. Diversification of sweet potato consumption will be enhanced if sweet potato flour and sweet potato starch processing plants are provided and policies put in place to encourage adding sweet potato flour to wheat flour in the preparation of bread.

\section{REFERENCES}

[1] Aboajah, F. N. (2009) Adoption of Improved sweet potato varieties and stereotyping of production activities across

sex-lines in Ishielu LGA of Ebonyi State, Nigeria. Proceedings of Agricultural Society of Nigeria Conference 2009, Abuja, Nigeria.

[2] Agbo, I. and Ene, C. S. O. (1992) "Status of Sweet potatoes Production and Resource in Nigeria" Sweet potato situation priority in Research in West Africa. Proceeding of Workshop held in Dolva, Cameroon from July $27^{\text {th }}$ to $29^{\text {th }}$ International Sweet Potato Center, Lima, Peru.

[3] Agricultural Policy for Nigeria - 1985

[4] Aldrich D. (1963). The sweet potato crop in Uganda. East African Agri. For. J. 29: 42-49.

[5] Azogu, I. and Olomo, V.O. (2002) "Processing Options for Roots Tubers under the RTEP Initiative: Constraints Opportunities. Paper presented at PTF Workshop, Makurdi, 17 $7^{\text {th }}$ August, 2002.

[6] Bashaasha, B., Mwanga, R.O.M., and Ocitti P'Obwaya, C.N. (1993). Sweet potato in the Farming and Food systems of Uganda. A farm survey report. Kampala Uganda.

[7] Beukema, J. and Van der Zaa (1990). Breeding sweet potato for high yields: A review.

[8] Chukwu G.O. (2001). Seasonality and Climate period effects on crop-transpiration of sweet potato. In Root Crops in $21^{\text {st }}$ Century Proceeding of the Seventh Triennial Symposium of the International Society for Tropical Root Crops-African branch, Akoroda, M. O. and Ngeve, J.M (eds) Cotonou Benin, $11^{\text {th }}-17^{\text {th }}$ Oct. 1998, pp 280- 284.

[9] Collins, J. L. and Abdul-Aziz, N. A. (1982). Test the effect of Sweet Potato to flour as an ingredients on quality of Yeast Raised Doughnuts.

[10] Devereau, A.D. and Bockett, G. N. A. (1994) Sweet Potato Storage- Is there a need to Improve traditional practice? Paper Presented at PRAPACE Workshop on sweet potato germplasm management, held in Mukono, Uganda, 31 August- 2 September, 1994.

[11] Ejechi, M. E; F .N. Aboajah; A. N. Imo and G. O. Chukwu (2009) "Determinants of Adoption of Improved Sweet potato Varieties across Gender in Ishielu L.G. A. of Ebonyi State, Nigeria" In: Proceedings of Agricultural Society of Nigeria Conference 2009, Abuja, Nigeria.

[12]Ewell, P. (1993) Sweet potato in African: Research Priorities to stimulate Increased Marketing .Paper presented atthe International Workshop on Methods for Agricultural Marketing Research, 16-20 March 1993, IARI Campus New Delhi, India.

[13] Ewell (1994). Sweet potato in the farming and food systems of Uganda. In: Akordao, M.O. (ed.). Root crops for food security in Africa. $5^{\text {th }}$ Triennial Symposium of the International Society for Tropical Root Crops Africa Branch (ISTRC-AB) Kampala Uganda, 22-28 November, 1992. 
[14]FAOSTAT handbook, FAO, 2008.

[15] Gakonyo, N. (1994). Processed sweet potato: Responding to Kenya's Urban Food Needs. Working paper in Agricultural Economics, Cornell University, July, 1993.

[16] Gatumbi, R. W., Kihurani, A.W., and Skoglund, L. G. (1992). Postharvest looses during transportation and handle of sweet potato in Kenya. Paper presented in Fifth Triennial Symposium of the ISTRC-African branch, 22-28 Nov. 1992, Kampala, Uganda.

[17] Hagenimena, V. and Oyunga M. A. (1995). Oil Content in Fried Sweet Potato proceeded production systems ofUganda. In: Akoroda, M. O. (ed). Roots crops Systems of Uganda. ISTRC-African branch, 2228 November, 1992 Kampala Uganda.

[18] Hagenimana, V., Simard, R. E., and Vezina, L.P. (1994) Amylolytic activity in germinating sweet potato (ipomoea batatats L.) root. Journal of American Society of Horticultural Science 119: 313-320

[19] Hagenimana, V. (1994). Report on trip to Uganda, July 18-29, 1994. International Potato Centre, SubSaharan Africa, Nairobi, Kenya.

[20] Hagenimana , V., and Owori, C. (1996). Feasibility, acceptability and production costs of sweet potato baked products in Lira Municipality, Uganda CIP/NRI and NARO, Uganda.

[21] Hall, A. J. (1995). An overview of sweet potato postharvest systems and constraints in Uganda Policy Options for Research. NRI report. In press.

[22] Hartwell, J. L. (1971) "Plants used against Cancer: A survey "Lioydia 30-34 Retrieved May, 9, 2006. http//www.hort.purdue.edu/newcrop/duke energy/ipomoea batatas, htm/\#uses.

[23] IITA (2002) Global 2000 Partnership on postharvest.

[24] Karuri, E.G., and Ojijo, N. K .O. (1994). Storage studies on sweet potato roots: Experiences with KSP 20 cultivar. Acta Horticulturae 368: 441- 452.

[25] Kihurani, A.W., Gatumbi, R.W. and Skoglund, L.G. (1991). Storage diseases of sweet potato in Kenya. Paper presented in $9^{\text {th }}$ Symposia of the ISTRC, 20-25 October, 1991. Accra Ghana.

[26] K'osambo, L .M., Carey, .E., Misra, A. K., Wilkes, J., and Hagenimana, V. (1998). Influence of age, farming site, and boiling on pro- vitamin A content in sweet potato (Ipomoea batatas) (L lam .) storage roots. Journals of Foods Composition and Analysis 11:305321.

[27] Matthew O. A. and Fatimoh A. A (2006) Profitability and Technical Efficiency of Sweet Potato Production.
[28] Nweke, F. I., and Akorche, A. (2002). Economic Impart of Improved Cassava Research and Extension.

[29] Odaga, A. (1992). Sweet Varieties of sweet potato can save on sugar and wheat flour in baking

[30] Ojijo, N.K.O. (1991). Objective evaluation of quality changes in stored sweet potatoes. Dissertation for a Master Degree, University of Nairobi, Kenya. P. 194

[31] Omosa, M. (1994). "Current and Potential demand for fresh and processed sweet potato products in Nairobi and Kisumu, Kenya". International Potato Centre, Nairobi.

[32] Onwueme , I. C. (1982). The tropical tuber crops: yams, cassava, sweet potato and cocoyam.

[33] Orodho, A. B., Alela, B . O., Wanambacha, J. W. (1995). Use of sweet potato (Ipomoea batatas L.) vines as starter feed and partial milk replacer for calves. KARI-Kakamega, Kenya.

[34] Oyunga, M.A. (1997). Oil content in fried processed sweet potato products.

[35] Reulinger, S. and Pellekan, J. V .H. (1986) Poverty and hunger: issues and option for food security in developing countries. Washington, D.C: The World Bank.

[36] Scott, G.J. (1992). Advances in Food and Nutrition Research. P 506

[37] Scott, G. J., Ferguson, P.I., and Herrera, J.E. (1992). Product development for Root and tuber crops. Vol. III-Africa. Proceeding of the Workshop on Processing, Marketing and utilization of Root and Tuber Crops in Africa, October 26- November 2, 1991. Ibadan, Nigeria.

[38] Sengooba, T. (1994). Roots crops for food security in Africa. Proc. $5^{\text {th }}$ Symp. ISTRC-AB: pp22-25

[39] Tewe O .O., Ojeninyi F. E., and Abu O. A. (2003) Sweet Potato Production, Utilization and Marketing in Nigeria Social Sciences Department, International Potato Centre (CIP), Lima, Peru.

[40] Wabwile, V. K., Ingasia, O. A. and Langat, J. K. (2016). Effect of Improved Sweet Potato varieties on household food security: empirical evidence from Kenya.

[41] Woolfe A.1992. Sweet potato: An untapped food resource. Cambridge University Press. Cambridge, U.K.

[42] World Healthiest Foods Book, 2017 